\title{
A Study of China's Elimination of Private Benefits of Control in State-owned Enterprises
}

\author{
Yanling Wang ${ }^{1}$ \\ ${ }^{1}$ China University of Political Science and Law, Beijing, China \\ Correspondence: Yanling Wang, China University of Political Science and Law, Beijing 100088, China. Tel: \\ 139-3688-9380. E-mail: 867578649@qq.com
}

Received: September 9, 2015 Accepted: September 26, 2015 Online Published: April 28, 2016

doi:10.5539/par.v5n1p45 URL: http://dx.doi.org/10.5539/par.v5n1p45

Fund Project: $<<$ the national social science fund project state-owned business as a research on construction of risk prtvetion $>>$ phased objectives.

\begin{abstract}
To eliminate control of state-owned enterprise managers of self-interest is a key problem for management of state-owned enterprises, the Chinese government has adopted a separate government functions from enterprise management, clear property rights, the board of directors system, assignment of the board of supervisors system, disciplinary leadership system reform, the mixed ownership and other measures, are difficult to eliminate the soe managers to seize control of self-interest, together with the present situation of China's state-owned enterprises, this paper proposed by the board of supervisors as the center of the corporate governance structure, powers and running of the reform of internal management mechanism, to try to eliminate the control gain, achieving the value of state-owned enterprises.
\end{abstract}

Keywords: eliminate state-owned enterprises control gain

\section{Introduction}

Chinese and overseas scholars generally believe that it is very important to eliminate the personal benefits of control ("PBC") by the managers of state-owned enterprises ("SOEs"). They define PBC as monetary gains, on-the-job consumption, non-monetary benefits and the power to decide on the allocation and use of enterprises' resources at managers' own discretion (Demsetz,1985), extravagant working conditions (Jensen, 2004), human capital increment (La porea, 2000), the appointment of incompetent family members or friends (Gebharde \& Schmidt, 2006), the transfer of assets through related-party transactions to companies controlled by relatives (Hart, 2001 ), the obtaining of illegal benefits through the disclosure of false information (Hall \& Nurphy, 2003; Ei-tan, 2006), or the obtaining of non-monetary benefits such as pleasure, sense of achievement and reputation (Holderness, 2003).

One of the most important features of modern enterprises is the separation of ownership and management. As long as managers do not completely own enterprises, they will act for their own interests and undermine shareholders' interests, which is called the agency problem. The elimination of PBC is a worldwide problem in large enterprises, and the agency problem is more serious in SOEs. All the countries are actively studying the measures to eliminate PBC in SOEs. In China's SOEs, the agency cost is high, equivalent to $60 \%-70 \%$ of the profit potential and resulting in the enterprise efficiency being just $30 \%-40 \%$. Since the reform of SOEs, China has been exploring ways to eliminate PBC, but existing measures are ineffective to eliminate PBC in SOEs. Therefore, finding a more appropriate solution is particularly important.

\section{China's Attempts to Eliminate Private Benefits of Control in State-owned Enterprises}

2.1 Building a Mixed Ownership Economy Is a Measure to Reduce the Agency Cost, but It Cannot Completely Eliminate $P B C$

Owing to SOEs' special status and contribution, SOEs are to some extent still an indicator of a country's GDP, labor market and capital market (OECD, 2005) even when the new liberalism and privatization are widely favored nowadays. For example, the SOEs of Singapore, New Zealand, France and the United States contribute 
$12 \%, 12 \%, 18 \%$ and $5 \%$ respectively to their GDPs, and SOEs enjoy an absolute advantage in the public utilities and infrastructure sector such as energy, transportation and telecommunication. As a socialist country, China's SOEs are pillars of the national economy. Although private capital participation can increase the diversity of SOEs' equity, promote further information transparency and thus enhance the monitoring of SOEs, it cannot eradicate SOEs' agency problem. The privatization of SOEs of the United Kingdom, the United States, Russia and other countries did not completely solve the agency problem, and corruption was still a serious problem in Enron and Lehman Brothers. Demsetz reckons that private ownership does not necessarily mean efficiency. When mutually affected parties involve a large number of people and harm or benefits are brought to just the people in a few parties, this will lead to high transaction costs and serious "free rider" problem even if private ownership is defined at its best. Public ownership can also produce high efficiency because the compelling power of the government can reduce transaction costs caused by unrestricted bargaining. After the comprehensive comparison of the operation results after the privatization of various types of enterprises in the United Kingdom (Martik \& Parker, 1997), market competition theorists Martik and Parker finds that the average beneficial results do not significantly change after the privatization of enterprises in the monopoly market and such benefits improve only in the fiercely competitive market.

According to theoretical studies and practices, managers' grabbing $\mathrm{PBC}$ is found in both private enterprises ("PEs") and SOEs. Therefore, it is unrealistic to seek the elimination of PBC through privatization or the building of a mixed ownership economy.

\subsection{Clear Ownership Is the Basis of the Supervision of State-Owned Assets, but Multiple Agency Will Breed Corruption}

According to the Decisions of the CPC Central Committee on Several Major Issues Concerning the Comprehensive Deepening of the Reform passed at the Third Plenary Session of the 18th CPC Central Committee, "State-owned enterprises belong to the whole people and they are an important force driving China's modernization and safeguarding people's common interests." According to Article 3 of the Law on the State-owned Assets of Enterprises, "State-owned assets shall belong to the State, namely, all the people. The State Council shall exercise the ownership rights to state-owned assets on behalf of the State." From the perspective of the trust law, all the Chinese people are beneficiaries (substantive right holders), the State is the principal, and the State Council is the trustee. It can be seen that Chinese laws have increasingly clearer provisions on the property rights to state-owned assets, and mature market economies also define the property rights to state-owned assets in this way, but after the clarification of property rights, they give more emphasis to the selection of the enterprise governance structures and the improvement of the power and operation mechanism to prevent the grabbing of PBC. China's SOEs are public companies with the most shareholders and the highest transparency, and serious $\mathrm{PBC}$ and rampant corruption tend to result from the long agency chain and the information asymmetry. Managers of China's SOEs play various tricks to grab PBC, bringing management risks such as overseas companies and management buy-out. They even transform state-owned and state-controlling Level-1 enterprises into purely holding companies not engaging in specific production or operation, and they usually allocate core quality assets and businesses to Level-2, Level-3 or Level-4 enterprises. Enterprise restructuring, related-party transactions, illegal guarantee, asset transfer and other links in the affiliated enterprises tend to result in the loss of state-owned assets. Obviously, ownership clarification is an essential condition for the elimination of PBC, but the multiple agency problem still exists after ownership clarification. Therefore, the enterprise operation and management mode must be innovated to establish an impeccable enterprise governance structure and eliminate PBC.

\subsection{The Boards of Directors of China's SOEs Cannot Become Representatives of Bona Fide Shareholders, and They Are still Agents of State-Owned Shareholders}

SOEs' ultimate owner is the State. As the "virtual owner", the State can only appoint its authorized institutions or authorities to exercise some of the functions and powers in the Boards of Shareholders. Such authorized institutions or authorities control SOEs, but they do not have the right to earnings or residual claims, and they do not bear residual risks. Therefore, they have no incentive to fully exercise the property rights to state-owned enterprises, they are indifferent to the efficiency of property rights, they even just consider grabbing PBC, and they tend to seek illegal gains from state-owned assets with SOE managers. The property rights to state-owned enterprises should be granted to economic entities or individuals bearing risks, entitled to earnings and exercising control, and such economic entities or individuals should be regulated by the authorized authorities of the State. SOEs' shareholders are all the Chinese people. The Members of the Boards of Shareholders are just authorized agents, and they are unlikely to truly exercise shareholders' rights and fulfill shareholders' obligations. Therefore, they tend to grab PBC, and the general meetings of shareholders become a mere formality. Members 
of the Boards of Directors also do not own SOEs, and they are likely to grab PBC in addition to earning salaries. Both the members of the Boards of Shareholders and the members of the Boards of Shareholders are likely to grab PBC by making use of their status in the making of major decisions such as the election of directors and supervisors, the formulation of major management principles and investment plans, the formulation and modification of articles of association, the formulation of budget plans, final account plans and plans for making up losses, the changes in registered capital, and enterprises' mergers, divisions or dissolutions. In addition, if managers are hegemonic, they are likely to dominate the Boards of Directors. Owing to the decentralization of shares, shareholders have a weak control, and managers can select directors through the control of the procedures for the selection of the members of the Boards of Directors. In this way, the Boards of Directors can only passively fulfill duties and responsibilities, and cannot control CEOs' performance. Consequently, the Boards of Directors are reduced to CEOs' tools. Weak Boards of Shareholders and Boards Of Directors cannot check or supervise managers. As a result, managers tend to be corrupt. SOEs' Boards of Directors cannot truly represent shareholders because they are just authorized agents to supervise state-owned assets. They are not highly different from or they are fundamentally the same as the Boards of Supervisors. Boards of Supervisors should be at the center of the governance structure, they should fully play the role of regulators, exercise the functions of the former Boards of Supervisors and some functions of the Board of Directors, establish the Boards of Executive Directors, and appoint managers for specific management.

After the establishment of the State-owned assets Supervision and Administration Commission (hereinafter "SASAC") of the State Council, the central and local authorities still have the powers to make major decisions concerning the major issues such as personnel and investments of large and medium-sized enterprises. Therefore, it is still difficult to secure effective corporate governance because senior executives headed by chairmen of the Boards of Directors or general managers have the power to actually control SOEs. SOEs attach importance only to financing, they do not attach importance to the establishment of the modern corporate governance structure, and for a long time, they rely on the government's recessive guarantee. Some local governments take SOEs as the platform of the development of the local economy and they even become one of SOEs' interested parties. In this way, local governments become SOEs' "protective umbrellas" and SOEs become governments' "money bags". As a result, the public powers tend to be abused, governments and enterprises unrestrainedly grab PBC, and corruption is rampant.

\subsection{The Boards of Supervisors Dispatched by Governments Can Supervise SOEs to Some Extent, but They Can only Exercise Ex-Post Supervision, and the Disciplinary Inspection and Audit Leadership System Needs to Be Reformed}

The internal Boards of Supervisors of China's SOEs largely perform no functions. They do not effectively exercise restraints on the Boards of Supervisors or the management, and they cannot air independent opinions on the loss of state-owned assets, false accounting information, improper related-party transactions and other issues. The Boards of Supervisors dispatched By the State Council or local governments to solely state-owned enterprises enhance governments' supervision of SOEs to a certain extent, and their status, professionalism and independence are all higher than the internal Boards of Supervisors. But these dispatched Boards of Supervisors also do not play their due role, and few of SOEs' problems are revealed by them.

Like SOEs' managers, the dispatched Boards of Supervisors are also agents for the supervision of state-owned assets, and the agency problem also exists. The dispatched supervisors do not have residual claims, and their interests do not have much to do with SOEs' performance. Therefore, such supervisors hardly have the incentive to supervise SOEs' managers, and they would rather live in peace with or even collude with SOEs' managers. The dispatched supervisors are mainly officials of government authorities, and whether they are competent for the supervision of SOEs remains a question because they do not have adequate surveys, inspections, time or energy for such supervision. Although according to the system design, the dispatched Boards of Supervisors should exercise the process supervision of SOEs rather than ex-post supervision, their supervision timeliness and effectiveness is significantly undermined because they have to report the identified problems to governments and cannot rectify the problems on the spot. Only light punishments are imposed on the supervisors not fulfilling their supervision responsibilities, for example, concealing SOEs' major violation of laws and disciplines or seriously neglecting their duties, colluding with SOEs' managers to falsify inspection reports, accepting SOEs' gifts or other benefits, and disclosing SOEs' secrets. As the supervisors not fulfilling their responsibilities are punished lightly, the cost of their collusion with managers to seek personal gains from state-owned assets is low. As a result, supervisors tend to perform practically no functions or even collude with SOEs' managers to grab PBC.

In CPC's dual leadership system for discipline inspection with Chinese characteristics, powers are not adequately 
constrained or supervised, and it is difficult to prevent PBC. CPC's local discipline inspection commissions at all levels are led by both the local CPC committees at the same levels and the discipline inspection commissions at higher levels. Although this system is called "dual leadership", local discipline inspection commissions are in fact mainly led by the local CPC committees at the same levels, and the leadership of the discipline inspection commissions at higher levels is weakened. Local discipline inspection commissions have been long subjected to local CPC committees at the same levels, it is difficult for them to supervise the latter. For example, corrupt local "top leaders" are rarely investigated by the discipline inspection commissions at the same levels and the intervention of the discipline inspection commissions at higher levels is necessary. This shows that the dual leadership system is dominated by the local CPC committees at the same levels, and the supervision of the local $\mathrm{CPC}$ committees at the same levels is seriously restrained.

2.5 The Hope of Elimination of PBC Should not Be Completely Placed on the Absolute Separation of Government Administration from Enterprise Management

According to the Decisions of the CPC Central Committee on Several Major Issues Concerning the Comprehensive Deepening of the Reform, in the natural monopoly industries where state-owned capital continues to be the controlling shareholder, the reform will be focused on the separation of government administration from enterprise management, separation of government administration from state-owned capital contribution, franchising, and government regulation. According to the express provisions in the OECD Guidelines on Corporate Governance of State-Owned Enterprises, states should be an informed and active owner, and the government should not participate in SOEs' daily management and should let SOEs operate independently. The separation of government administration from enterprise management does not mean that the government no longer regulates enterprises but means that the government should exercise its power as the owner in the legal framework of each enterprise, attend shareholders' meetings and cast votes as holders of state shares, establish good and transparent director appointment procedures, establish the reporting system for the supervision and assessment of SOEs' performance, and ensure the remuneration mechanism and talent training for the members of the Boards of Directors. It is impossible to completely separate SOE management from government administration. As the owner appointed by the people, the government must regulate SOEs, and the complete separation of government administration from enterprise management will be equivalent to privatization, which is inconsistent with China's national conditions and also distorts the original intention of SOE reform. The United Kingdom, New Zealand, Australia and other countries all carried out large-scale privatization, but they all retain SOEs and subject SOEs to the supervision of the governments and the parliaments. Canada's parliament, governors and competent ministers have the power to approve of the establishment, dissolution or privatization of SOEs, set SOEs' management objectives, annually accept and examine SOEs' relevant information (including approved plans and budget summaries), approve SOEs' annual reports, approve of the appointment and remuneration of SOEs' CEOs and the members and the chairmen of SOEs' Boards of Directors, approve SOEs' plans based on the suggestions of competent ministers and finance committees, approve of the establishment and dissolution of SOEs' subsidiaries, and appoint SOEs' auditors every year. In the United States, the members of SOEs' top management are nominated by the president, approved by the congress and appointed by the president, and they have high degree of autonomy in operation. The members of the Boards of Directors are nominated by the government and approved by the congress. The French government manages SOEs through the appointment and dismissal of the chairmen of the Boards of Directors and the general managers. The German government leads SOEs mainly through the Boards of Supervisors, whose composition is complex: chairmen are persons trusted by shareholders and appointed by the finance minister, and the vice chairmen are employees' representatives. The employees of Japan's SOEs are civil servants and managed in accordance with the laws on local civil servants. The chairmen of the Boards of Directors of South Korea's SOEs shall not be concurrently general managers or civil servants, and they are nominated by the competent ministers and appointed by the president.

Generally speaking, the important issues of SOEs of mature market economies are all decided by the governments: governments establish standardized corporate governance structures, give full autonomy to SOEs, strengthen the supervision of SOEs, prevent the grabbing of PBC, and improve SOEs' efficiency. As a socialist country, China cannot completely separate enterprise management from government administration and can only separate ownership and management.

In short, in the elimination of SOEs' PBC, although existing measures have produced some effects, they cannot completely eliminate $\mathrm{PBC}$ and corruption is spreading. Therefore, it is urgently needed to find the SOE management measures with Chinese characteristics in combination with China's national conditions and starting from SOEs' internal governance structure. 


\section{Establishing the Corporate Governance Structure with the Board of Supervisors at the Center Is an Important Measure in Line with China's Actual Conditions}

The power to decide on the election of the Boards of Directors by SOE's general meeting of shareholders is vested in the managers of state-owned assets. The agency problem exists whatever the composition of the Boards of Directors. The Boards of Directors are not truly shareholders' representatives, and they mainly function in the supervision of SOEs, barely different from the role of the Boards of Supervisors. In the countries adopting the typical modern enterprise system, Germany's SOEs place the Boards of Supervisors above the Boards of Directors and strengthen the supervisory role, which is suitable for China's a large number of multi-leveled SOEs troubled by rampant grabbing of PBC. The multi-leveled leadership system with the Boards of Supervisors at the center can better play the role of the Party organizations in SOEs and reduce the number of agency levels so that the Party committees are directly integrated into the Boards of Supervisors to achieve the integration of the old "Party committees, workers ' congresses and trade unions" with the new "Boards of Shareholders, Boards of Directors and Boards of Supervisors", fully play the supervisory role of the Boards of Supervisors and ensure the effectiveness of the supervision of the Boards of Supervisors, rather than ex-post supervision. In addition, China has many SOEs and in the design of the modern enterprise system, supervision should be emphasized and overall considerations should be taken in the design of the supervision levels: the businesses of the groups and Level-2 companies to prevent "shell companies", and the governance structures of Level-2 and Level-3 companies should be improved to establish the multi-leveled management system with the Boards of Supervisors at the center so that the relationships between parent companies and subsidiaries can be straightened out and the clean governance risks can be controlled.

\subsection{Division of Functions/Powers and Operating Mechanism of the Boards of Supervisors and the Boards of Directors}

The dual board system should be implemented, and it should be made up of the Boards of Supervisors and the Management Boards: the Boards of Supervisors focus on supervision, while the Management Boards independently manage SOEs. The Management Boards are somewhat subjected to the resolutions of the Boards of Supervisors, rather than the instructions of the general meetings of shareholders. Directors are appointed by the Boards of Supervisors and cannot be legal representatives. Without the permission of the Boards of Supervisors, directors shall not engage in any commercial activities or personal dealings of the same types as SOEs' operating activities, and shall not become the directors or actual managers of any other companies. This will eliminate the risk that the Boards of Supervisors practically only exercise ex-post supervision and prevent corruption, achieving the integration of the ex-ante, while-event and ex-post supervision.

SASAC leads SOEs mainly through the Boards of Supervisors, whose composition is complex: chairmen are persons trusted by shareholders and appointed by SASAC, and the vice chairmen are employees' representatives. All major decisions of the Boards of Supervisors are to be discussed in advance by the presidia of the Boards of Supervisors. The numbers of the members of the Boards of Supervisors depend on SOEs' sizes. There should be detailed procedures for the selection of employees' representatives, and voting rights should be granted to certain proportions of blue-collar employees, white-collar employees and managers. The triangular system is generally adopted. In other words, there are several external supervisors represented by shareholders (in the enterprises controlled by state-owned capital, such external supervisors are appointed by SASAC and the Organization Department), several employees' representatives and several internal representatives (secretaries of the Party committees, secretaries of discipline inspection, executive directors and managers) of SOEs' management. In Boards of Supervisors, the majority voting system is adopted, and if votes are equally divided, the presidents will cast the second votes. The government representatives dispatched by SASAC to the Boards of Supervisors control the Boards of Supervisors.

The Boards of Executive Directors take charge of enterprises' daily management and must regularly report enterprises management principles, profitability, operation processes, capital turnover, major issues and subsidiaries' very important transactions to the Boards of Supervisors. The Boards of Supervisors appoint the members of the Boards of Executive Directors, supervise such members' activities and decide their remunerations, formulate enterprises' management principles, may at any time require the Boards of Executive Directors to introduce the issues having significant effects on enterprises, and may examine enterprises' account books and records by themselves or via experts.

SASAC and other governmental authorities also supervise SOEs. SASAC has the power to raise suggestions on major issues on SOEs' establishment and fund supply, but such issues are decided by the National People's Congress and the Standing Committee of the National People's Congress. But like the Boards of Supervisors, the 
National People's Congress cannot directly interfere with SOEs' general business, and it can only legislate the basic principles which shall be followed by the Boards of Directors. SASAC is directly responsible for the supervision of state-owned assets and it has the power to supervise SOEs' payments and receipts and safeguard state-owned assets. SOEs' stock purchases and sales, original capital changes, other changes and degrees of government involvement are subject to SASAC's prior approvals. SASAC supervises and controls SOEs' at least following issues: inspect the preparations of the Boards of Supervisors three to four times a year; inform the members of the Boards of Supervisors of the government's political intentions; to prepare for management policies and personnel arrangements; approve of the State's participation in the purchase, capital increase or sale of SOEs; control SOEs' quarterly reports and inform the Audit Office of the relevant information; and prepare documents for the relevant sub-committees of the Standing Committee of the National People's Congress.

3.2 The Core Role of the Party Organization in SOEs Should Be Strengthened to Achieve the Integration of the Old "Party Committees, Workers ' Congresses and Trade Unions" with the New "Boards of Shareholders, Boards of Directors and Boards of Supervisors"

The secretaries of the Party committees and the secretaries of discipline inspection are members of the Boards of Supervisors, and they are directly in charge of the Boards of Auditors and the Boards of Remuneration and Nomination, and enhance the control of SOEs. The Boards of Supervisors adopt the majority voting system, and weaken the superior-subordinate relationship in the Party and government posts, so that "top leader's final say" can be avoided in the making and implementation of major decisions. The secretaries of the Party committees and the secretaries of discipline inspection supervise the operation of SOEs' Boards of Supervisors and Boards Of Directors, and formulate the specifications for the holding of the meetings of the Boards of Supervisors, the Boards of Directors and the specialized boards. The Party committees and the Boards of Supervisors are integrated, and employees are members of the Boards of Supervisors, so that the Party committees and the trade unions play their roles in the Boards of Supervisors. In case of major issues such as the establishment or merger of enterprises, the general meetings of employees and the general meetings of shareholders are held in combination. In SOEs, only managers and employees truly bear residual risks and any other persons almost bear no residual risks; therefore, managers and employees may pay closer attention to enterprises' growth and development than any other persons. Employees and non-state-owned shareholders are both concerned about enterprises' survival and development. Therefore, enterprises' major decisions are made jointly at the general meetings of employees and the general meetings of shareholders.

\subsection{Reform of SOEs' Incentive Mechanism}

Granting residual claims and control powers to managers will converge the interests of managers and shareholders and mitigate the agency problem to some extent. Granting certain residual claims to supervisors can prevent supervisors' and managers' collusion in the grabbing of state-owned assets; involving employees in corporate governance bring enterprises' interests much closer to employees' interests and help create common beliefs and values; consequently, with employees' involvement in corporate governance, the residual losses are fewer than those in the traditional sense. According to the empirical study by Conte and Svejnar, the companies involving employees in management are more productive. Establishing a scientific and reasonable mechanism for the assessment and incentive of the performance of SOEs' leaders is an important aspect of the prevention and control of clean governance risks. After assessment, the regulatory authorities for state-owned assets pay remunerations to SOEs' managers and supervisors. Consideration should be given to the transformation of the remuneration system from "base salaries + risk premiums" to "base salaries + yearly performance bonuses + incomes from equities and options + benefit plans". Managers and supervisors may serve consecutive terms to prevent the short-term actions of SOEs' leaders, so that SOEs' leaders pursue the maximization of long-term interests so as to achieve SOEs' strategic goals of long-term development. In terms of spiritual incentives, appropriate social status and honorary titles should be granted to managers of large and medium-sized SOEs, and such managers' creative work should be publicized on various media, so that managers become a respected and admired occupation and enjoy a good growth environment and social atmosphere.

\subsection{Reform of SOEs' Personnel System}

SOEs' employees should be civil servants. According to the law on civil servants, the highest decision-making body and the daily executive body should be set for personnel management, and the committee consultation system should be adopted in the highest decision-making body. The members of committees should be selected from all walks of life, the appointment and dismissal of the members and enterprises' heads should be subject to SASAC's approval, and the presidents and other heads of the executive bodies should be appointed by the Boards of Supervisors. The appointment and dismissal of major managers, the scope of business activities, the 
budgets, the profit distribution plans, the financing activities, the salary determination methods and other aspects of central enterprises should be approved by the National People's Congress or approved or agreed on by SASAC and the Organization Department of the CPC Central Committee, and major responsible officers can serve consecutive terms with each term ranging from 2 to 5 years. The international professional manager system should be implemented, more promising talents should be selected, reserve managers should be identified, and high-level managers should be adequately trained.

Although CPC and the government have designed a series of systems for SOEs since the Third Plenary Session of the 18th CPC Central Committee, there still exist clean governance risks such as imperfect systems and incomplete implementation of SOEs' systems. Therefore, multiple measures and multiple channels should be made use of together to establish more effective governance structures for SOEs, so that SOEs' managers cannot grab PBC and must exercise powers in accordance with the applicable provisions. Through this, a good system has been formed to prevent and eliminate corruption.

\section{References}

Demsetz. (1999). Ownership, Control and Enterprises. Beijing: Economic Science Press, 342.

Li, J. W. (2005). Corporate System, Corporate Governance and Corporate Management: the Position and the Role of Laws in Corporate Management. Beijing: People's Court Press, 87.

Li, M. H. (2005). On the Boards of Supervisors of State-owned Enterprises. Journal of Shanxi University of Finance and Economics, (12).

Liu, J. H. (2013). Legal Thoughts about Deepening the Transformation of State-owned Enterprises into Companies. Journal of the Party School of the CPC Central Committee, (12).

Liu, Y. G. (2008). A Study of the Governance of State-owned Enterprises. Beijing: Press of the University of Science and Technology of China, 118.

Ping, X. Q. (2003). An Empirical Analysis of the Agency Cost in China's State-owned Enterprises. Economic Research Journal, (11).

Wang, Y. L. (2014). Reform of SOEs' Leadership System and Prevention and Control of SOEs' Clean Governance Risk. Jilin: Jilin University Press, 97.

Zheng, S. M. (2012). A Study of the Role of Governments in Corporate Governance -- Based on the Analysis of China's State-owned Listed Companies. Beijing: Economy \& Management Publishing House, 10.

\section{Copyrights}

Copyright for this article is retained by the author(s), with first publication rights granted to the journal.

This is an open-access article distributed under the terms and conditions of the Creative Commons Attribution license (http://creativecommons.org/licenses/by/3.0/). 